\title{
Influence of a Base Reflector on the Performance of Double Exposure Box- type Solar Cookers with and without Heat Storage Materials
}

\author{
Babatunde O. Adetifa \\ Lecturer \\ Olabisi Onabanjo University \\ Department of Agricultural Engineering \\ Nigeria

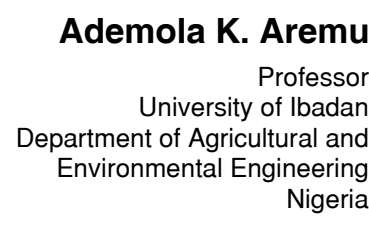

\section{INTRODUCTION}

Over the years, reflectors have been an important component of solar cookers and in other solar thermal applications. Solar concentrators/reflectors direct solar energy onto the absorber area for producing sufficient heat energy for cooking [1]. Different materials have been applied for solar cookers such as; mirror, lens, glass, reflective paints, reflective sheets and foils, etc. These reflectors can be applied directly or indirectly to heat up the pots [2] or in form of a non-tracking concentrator [3].

According to World Intellectual Property Organization [1], 31\% of the heat-trapping (i.e. box type) solar cookers patented make use of a reflector/concentrator, while 35.2 and $7.8 \%$ of these cookers used a mirror and sheets/foils respectively. Placing the reflector above the box/chamber to direct the sunrays inside the cooking chamber/box is the common reflector arrangement of these cookers [1].

There have been advances in solar cooker design which have to do with the adjustment of certain factors pertaining to the reflectors, some of which include;

i. Changing the reflector materials: Presently, there are two major types of reflective material used for the solar cooker, which are glass mirror and vacuum

Received: June 2017, Accepted: May 2018

Correspondence to: Adetifa B.O., Department of

Agricultural and Mechanical Engineering, Olabisi

Onabanjo University, Ibogun, Nigeria

E-mail: olusola.adetifa@oouagoiwoye.edu.ng

doi:10.5937/fmet1804567A

(C) Faculty of Mechanical Engineering, Belgrade. All rights reserved aluminium film. The early solar cookers always adopted glass mirror as reflecting material. The aluminium film, with characteristics of high reflectance and easy replacement, were used for the commercialized solar cooker product. The lifetime of the aluminium film is 2-3 years [4]. The solar cooker with polished aluminium reflectors has significantly lower performance than that of the glass mirror reflectors, under clear sky conditions [5], although they are durable.

ii. Increasing the size of the reflectors: Increasing the size of the reflector will increase net energy [6].McCluney[7]reported that if the front and back reflectors of a solar cooker are extended to intercept substantially more flux from the sun (at a high sun angle), there will be an increase in performance because excessive numbers of rays will not miss the target.

iii. Changing the angle of the reflectors: According to an experimental investigation carried out by Arabacigil et al.[8], the optimum angle for the outer reflector of a box solar cooker is $30^{\circ}$. This conclusion was based on the investigation of the thermal efficiency of a box-type solar cooker with four outer reflectors at $30^{\circ}, 45^{\circ}$ and $60^{\circ}$ angles of inclination. The thermal efficiencies were approximately 68.70 , 51.50 and $50.10 \%$ respectively.

iv. Increasing the number of reflectors: Ekechukwu and Ugwuoke[9] reported absorber plate tempe-ratures of $138^{\circ} \mathrm{C}$ and $119^{\circ} \mathrm{C}$ for solar cooker with and without the plane reflector respectively and respective boiling times of 60 minutes and 70 
minutes for $1 \mathrm{~kg}$ of water. Similarly,Mohammed et al.[10] reported stagnation absorber plate temperatures of $145^{\circ} \mathrm{C}$ and $137{ }^{\circ} \mathrm{C}$ for a truncated pyramid solar cooker with and without a booster-mirror reflector. Nahar[11] also reported thermal efficiencies of $30.5 \%$ and $24.5 \%$ for a double and single reflector hot box solar cookers respectively. Four reflectors can be conveniently used to concentrate solar radiation similar to tracking reflectors, but without the hazards of frequent manual adjustment to follow the apparent motion of the sun [12]. Martin et al.[13] observed that in a parametric solar cooker, the peak air temperature of the cooker with four reflectors was approximately $20^{\circ} \mathrm{C}$ higher than the cooker with only one reflector.

v. Increasing the faces exposed to solar radiations: Amer[14] developed a double exposure solar cooker with a set of plane diffuse reflectors which directed solar radiation onto the lower side of the absorber plate. The absorber plate and the air inside of the double exposure cooker attained a temperature which was 25 and $23^{\circ} \mathrm{C}$ higher than that of a boxtype solar cooker under similar operating conditions. The double exposure solar cooker has better performance than the single exposure solar cooker in terms of first figure of merit [15] and energy/exergy analysis [16].

There are different designs of a double exposure boxtype solar cooker (DEBSC) available, but there has been no detailed study to justify why the bottom of a box-type solar cooker was exposed and to show the type of contribution the base reflector has on the overall performance of the DEBSC with and without heat storage. In view of this, this paper is aimed at experimentally investigating the effect of the presence and absence of the base reflector on a DEBSC with and without heat storage.

\section{MATERIALS AND METHODS}

\subsection{Double exposure box-type solar cooker (DEBSC)}

This solar cooker has a permanently positioned cooking pot surrounded by an annular cavity which contains the heat storage material. The cooker was covered at the top with a double glazing cover and it has three plane reflectors to boost the collection of solar insolation. The bottom of the cooker was opened for exposure to solar radiation from a parabolic reflector placed below the cooker. The four different DEBSCs developed are;

1. DEBSC with no heat storage (NHS)

2. DEBSC with latent heat storage (LHS) -4.5 $\mathrm{kg}$ of benzoic acid (latent heat of fusion, $L_{\mathrm{f}}=$ $142.8 \mathrm{~kJ} / \mathrm{kg}$ and melting point, $M_{\cdot \mathrm{pt}}=121.7^{\circ} \mathrm{C}$ ) (estimated from (1))

$Q=M_{h s} L_{f}$

3. DEBSC with latent heat storage (LHS) $-4 \mathrm{~kg}$ of stearic acid $\left(L_{\mathrm{f}}=160 \mathrm{~kJ} / \mathrm{kg}, M_{\cdot \mathrm{pt}}=55.1{ }^{\circ} \mathrm{C}\right)$ (estimated from equation 1)

4. DEBSC with sensible heat storage (SHS) -5.4 $\mathrm{kg}$ of palm olein oil which will attain $100{ }^{\circ} \mathrm{C}$ from $25{ }^{\circ} \mathrm{C}$ (Specific heat, $C=169 \mathrm{~kJ} / \mathrm{kg}$ and density, $\rho=900 \mathrm{~kg} / \mathrm{m}^{3}$ ) (estimated from (2))

$$
Q_{h s}=M_{h s} L_{f}
$$

The different masses of the heat storage materials are the amount required to store $630 \mathrm{~kJ}$ of energy, $Q$ (energy required to boil $2 \mathrm{~kg}$ of water from $25^{\circ} \mathrm{C}$ ).

\subsection{Experimentation}

The four DEBSCs were used in water heating under solar radiation. The influence of the base reflectors on the performance DEBSCs was investigated by initially exposing the base reflectors to solar radiations (figure 1a) and later closing it (figure 1b).

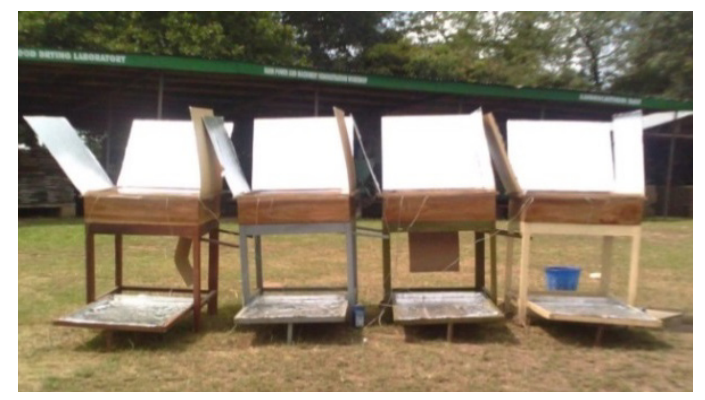

Figure 1a. Experimental setup of DEBSCs with the base reflectors exposed

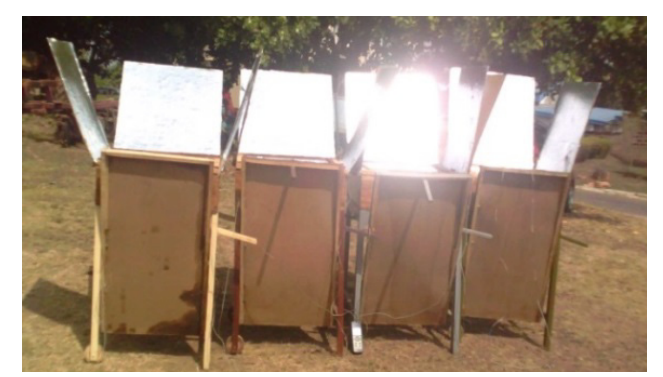

Figure 1b Experimental setup of DEBSCs with the base reflectors closed

Instrumentation and Setup: The instruments used in this experiment are thermocouples, multi-channel temperature logger and indicator, solar meter, digital weighing balance and water. The solar cookers were set up in an open area facing the direction of the sun. Care was taken to ensure that shadow was not cast on the surface of the cooker. From figure 2, the hot junction of the thermocouples was fixed at the absorber plate (point A), inside the pot (point B) and the heat storage material (point $\mathrm{C}$ ), while the other ends were connected to the multichannel temperature logger and indicator.

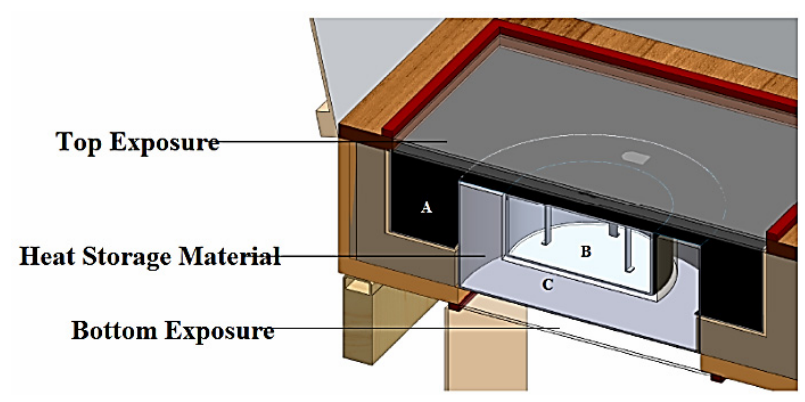

Figure 2 Location of thermocouples in the DEBSC

Experimental Procedure: The following steps were carried out when the base reflectors were exposed and when closed to solar radiation. 
1. The experiment started when the intensity of the solar radiation was above $800 \mathrm{~W} / \mathrm{m}^{2}$

2. $1 \mathrm{~kg}$ of water was filled into each of the pots in the DEBSCs.

3. The temperature of the water in the pots of each of the cookers were recorded at $30 \mathrm{se}-$ conds interval using the multi-channel temperature logger

4. The temperature of the heat storage material, ambient and the absorber plate were monitored and recorded every 10 minutes using a multichannel temperature indicator.

5. The intensity of solar radiation was measured using a digital solar meter. The readings were taken at the level of the DEBSCs within 10 minutes interval.

The experiment lasted for three hours

\subsection{Performance Evaluation}

The thermal performance of the solar cooker was evaluated by estimating the heating power and sensible heat efficiency (SHE) using (3) and (4), respectively.

$$
\begin{aligned}
& \dot{Q}_{w}=\frac{M_{w} C_{w} \Delta T_{w}}{\Delta t} \\
& S H E=\frac{\dot{Q}_{w}}{I_{0} A_{S}}
\end{aligned}
$$

Where; $\dot{Q}_{w}$ is the water heating power $(W), \mathrm{M}_{\mathrm{w}}$ is the mass of water heated $(\mathrm{kg}), \mathrm{C}_{\mathrm{w}}$ is the specific heat capacity of water $(\mathrm{J} / \mathrm{kg} \mathrm{K}), \Delta \mathrm{T}$ represents the difference between an initial and final water temperature $(\mathrm{K})$ and $\Delta \mathrm{t}$ is the time difference (sec). $I_{\mathrm{o}}$ is the intensity of solar radiation $\left(\mathrm{W} / \mathrm{m}^{2}\right)$ and $A_{\mathrm{s}}$ is the surface area of the glazing of the DEBSC.

The amount of energy stored in the heat storage materials in the DEBSCs was estimated using (5).

$$
Q=M_{h s} C_{h s} \Delta T_{h s}
$$

where; $Q_{\mathrm{hs}}$ is the energy stored in the heat storage materials $(\mathrm{kJ}), M_{\mathrm{hs}}$ is the mass of the heat storage materials used $(\mathrm{kg}) . C_{\mathrm{hs}}$ is the specific heat capacity of the heat storage materials $(\mathrm{kJ} / \mathrm{kg} . \mathrm{K})$ and $\Delta T_{\mathrm{hs}}$ represents the difference between an initial and final temperature of the heat storage materials $(\mathrm{K})$.

When the heat storage materials melt, the amount of energy stored was estimated using (6).

$$
Q_{h s}=M_{h s} L_{f}
$$

where; $L_{f}$ is the latent heat of fusion of the heat storage material $(\mathrm{kJ} / \mathrm{kg})$.

\section{RESULTS AND DISCUSSION}

\subsection{Ambient Conditions}

Figure 3 shows the solar radiation and the ambient temperature when the tests were conducted. The first test (closing the base reflectors) was carried out under an average solar radiation of $957 \mathrm{~W} / \mathrm{m}^{2}$ with a minimum value of $832 \mathrm{~W} / \mathrm{m}^{2}$ and a maximum value of $1048 \mathrm{~W} / \mathrm{m}^{2}$, while the ambient temperature was $36.1{ }^{\circ} \mathrm{C}$ having minimum and maximum values of 32.5 and $38.1{ }^{\circ} \mathrm{C}$ respectively. The second test (opening the base reflector) was carried out under an average solar radiation of 908 $\mathrm{W} / \mathrm{m}^{2}$ with minimum and maximum values of 207 and $1137 \mathrm{~W} / \mathrm{m}^{2}$ respectively, while the average ambient temperature was $35.3{ }^{\circ} \mathrm{C}$ with minimum and maximum values of 31.9 and $37.0^{\circ} \mathrm{C}$ respectively.

The ANOVA conducted at ambient temperatures and the solar radiations of the two days revealed that at $5 \%$ level of significance, there was no significant difference between readings of the two days (Table 1). This further implies that these ambient conditions did not contribute to the difference in the performance of the DEBSCs across the two days.

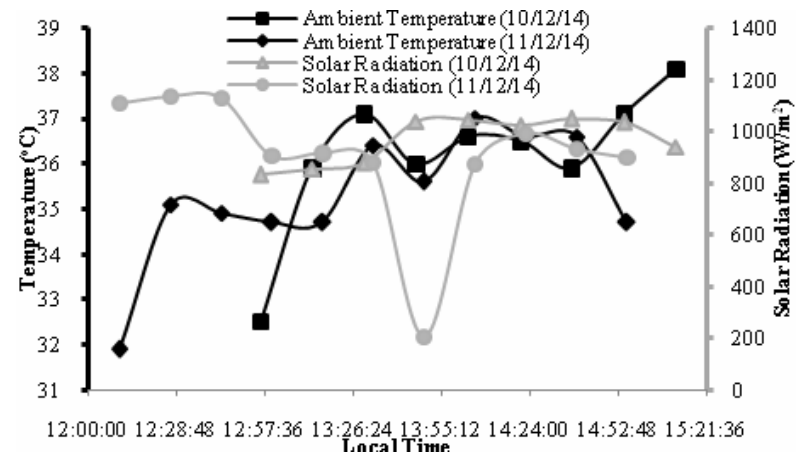

Figure 3 Ambient conditions during experiment

Table 1. ANOVA between the ambient conditions of the two days of experimentation

\begin{tabular}{ccc}
\hline Ambient condition & P-value & Inference \\
\hline Solar Radiation & 0.42 & Not Significant \\
Ambient Temperature & 0.20 & Not Significant \\
\hline
\end{tabular}

\subsection{Water Temperature}

Figures $4 \mathrm{a}-\mathrm{d}$ show the water temperature of the DEBSC with no heat storage material, with benzoic acid, with stearic acid and with palm olein respectively when their base reflectors were used and when they were not. Without a base reflector, the DEBSC with no heat storage attained a maximum temperature of $73.3{ }^{\circ} \mathrm{C}$; while when the base reflector was used, it attained $93.0{ }^{\circ} \mathrm{C}$ (Figure $4 a)$. For the DEBSC with benzoic acid, without using the base reflector, the maximum water temperature attained was $81.0^{\circ} \mathrm{C}$, while using the base reflector gave rise to a maximum water temperature of $94.1{ }^{\circ} \mathrm{C}$ (Figure $4 \mathrm{~b}$ ). Figure $4 \mathrm{c}$ shows that without the base reflector, the DEBSC with stearic acid heated water to a maximum temperature of $68.9{ }^{\circ} \mathrm{C}$ compared to $84.7{ }^{\circ} \mathrm{C}$ attained when the base reflector was used. The DEBSC with palm olein as heat storage attained a maximum water temperature of $75^{\circ} \mathrm{C}$ without the base reflector, but 81.7 ${ }^{\circ} \mathrm{C}$ with the base reflector in use (Figure 4d).

These results clearly show that using the base reflectors boosted the water temperature rise in the DEBSCs. Without any heat storage material, a boost of $20{ }^{\circ} \mathrm{C}$ can be attained, while depending on the type of heat storage materials used, a boost of around $6-15{ }^{\circ} \mathrm{C}$ can be attained. Also, since these results are comparable to those reported for other solar thermal systems [1720], a double exposure system can be applied. 


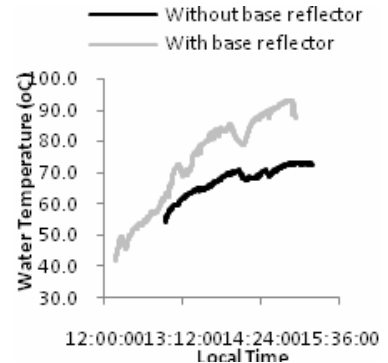

(a)

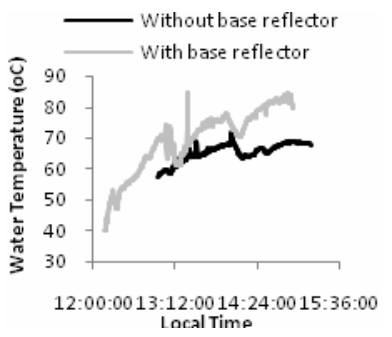

(c)

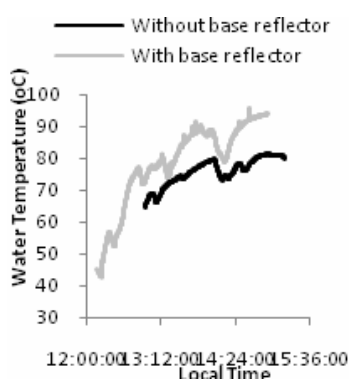

(b)

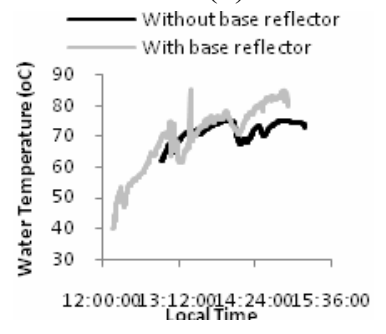

(d)
Figure 4. Water temperature in the DEBSCs with and without base reflectors (a: DEBSC with no heat storage material; b: DEBSC with benzoic acid; c: DEBSC with stearic acid; DEBSC with palm olein)

Figures $5 \mathrm{a}-\mathrm{d}$ show the trend of the change in water temperature of the DEBSC with no heat storage material, with benzoic acid, with stearic acid and with palm olein, respectively when the base reflectors were used and when not in use. This trend shows the stability of the temperature change. This stability is affected by heat losses, the behaviour of the heat storage materials and the fluctuation in solar radiation. The temperature change in the DEBSCs without base reflectors was observed to be more stable compared to when the base reflectors were used. With the base reflectors, the overall temperature change per minute rangedbetween -4 to $4,-3$ to $5,-11$ to 5.6 and -1 to $2{ }^{\circ} \mathrm{C}$ for the DEBSC with no heat storage material, with benzoic acid, with stearic acid and with palm olein, respectively. Without the base reflectors, the overall temperature change per minute ranged between -1 to $1,-2$ to $1,-3$ to 3 and -2 to 1 for the DEBSC with no heat storage material, with benzoic acid, with stearic acid and with palm olein, respectively.

The high positive values attained when the base reflectors were in use shows that base reflectors were effective in increasing the temperature of the DEBSCs. On the other hand, the high negative value of the temperature change was due to the heat loss at the bottom of the DEBSC when it was exposed to the solar radiation reflected by the base reflector.

\subsection{Water Heating Power}

The water heating power of the DEBSCs (with and without base reflectors) containing no heat storage material, with benzoic acid, with stearic acid and the one with palm olein oil for heat storage are shown in figures $6 \mathrm{a}-\mathrm{d}$. The heating power was observed to be higher when the base reflectors were used. Figure $6 a$, using a base reflector in a DEBSC with no heat storage gave rise to a maximum heating power difference of $112 \mathrm{~W}$ and a stabilized difference of 11-20 W over a period of 94 min compared to when the base reflectors where not used. Figure $6 \mathrm{~b}$ also shows that using a base reflector in a DEBSC with benzoic acid for heat storage gave rise to a maximum heating power difference of 60 $\mathrm{W}$ and a stabilized difference of $10-25 \mathrm{~W}$ over a period of 34 min compared to when the base reflectors were not used. Figure $6 \mathrm{c}$ shows that a base reflector in a DEBSC with stearic acid has storage material gave rise to a maximum heating power difference of $172 \mathrm{~W}$ and a stabilized difference of 12-22 $\mathrm{W}$ over a period of $62 \mathrm{~min}$ compared to when the base reflectors where not used. Similar to figure $6 \mathrm{a}$, figure $6 \mathrm{~d}$ shows that using a base reflector in a DEBSC with palm olein as heat storage material gave rise to a maximum heating power difference of $35 \mathrm{~W}$ and a stabilized difference of 9-20 $\mathrm{W}$ over a period of $92 \mathrm{~min}$ compared to when the base reflectors where not used.

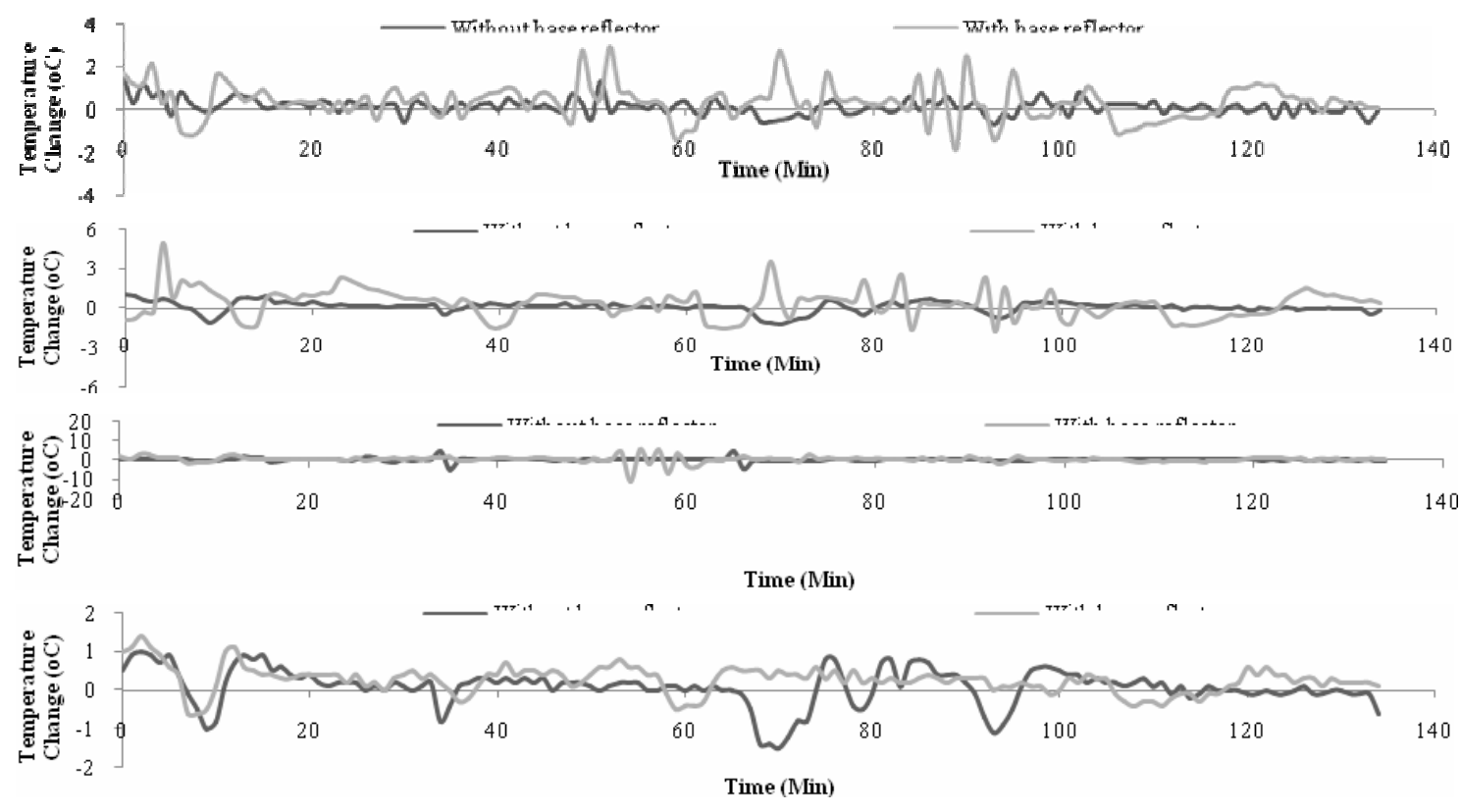

Figure 5. Change in water temperature in the DEBSCs with and without base reflectors (a: DEBSC with no heat storage material; b: DEBSC with benzoic acid; c: DEBSC with stearic acid; DEBSC with palm olein) 


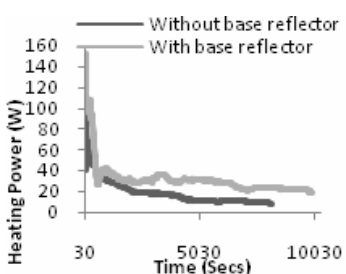

(a)

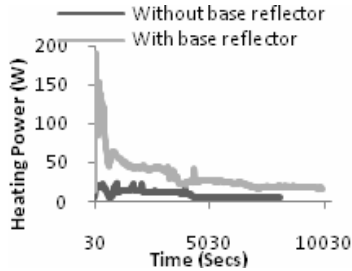

(c)

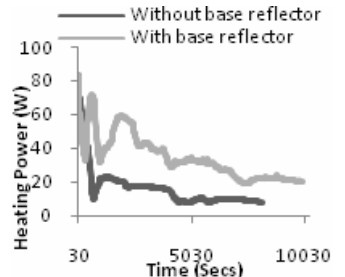

(b)

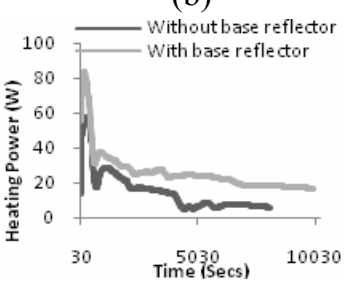

(d)
Figure 6. Water heating power of the DEBSCs with and without base reflectors (a: DEBSC with no heat storage material; b: DEBSC with benzoic acid; c: DEBSC with stearic acid; DEBSC with palm olein)

\subsection{Sensible Heating Efficiency (SHE)}

Table 2 shows the SHE summary statistics of the four DEBSCs with and without base reflectors. Using a base reflector makes the DEBSCs attain a higher SHE. This was clearly due to the increase in the exposure points.

Table 2. Summary statistics of the SHE of the DEBSCs with and without base reflectors

\begin{tabular}{cccccc}
\hline DEBSC & $\begin{array}{c}\text { Mean } \\
\text { SHE }\end{array}$ & $\begin{array}{c}\text { Standard } \\
\text { Deviation }\end{array}$ & Range & Min & Max \\
\hline $\mathrm{NHS}_{\mathrm{a}}$ & 0.080 & 0.060 & 0.410 & 0.034 & 0.444 \\
$\mathrm{NHS}_{\mathrm{b}}$ & 0.160 & 0.120 & 0.452 & 0.080 & 0.532 \\
${ }^{1} \mathrm{LHS}_{\mathrm{a}}$ & 0.066 & 0.054 & 0.352 & 0.029 & 0.381 \\
${ }^{1} \mathrm{LHS}_{\mathrm{b}}$ & 0.171 & 0.119 & 0.494 & 0.082 & 0.577 \\
${ }^{2} \mathrm{LHS}_{\mathrm{a}}$ & 0.041 & 0.022 & 0.089 & 0.019 & 0.109 \\
${ }^{2} \mathrm{LHS}_{\mathrm{b}}$ & 0.163 & 0.117 & 0.603 & 0.048 & 0.650 \\
$\mathrm{SHS}_{\mathrm{a}}$ & 0.064 & 0.055 & 0.244 & 0.019 & 0.263 \\
$\mathrm{SHS}_{\mathrm{b}}$ & 0.130 & 0.094 & 0.351 & 0.068 & 0.419 \\
\hline
\end{tabular}

Where; NHS: No heat Storage, LHS: Latent heat storage,

SHS: Sensible heat storage, a: Without a base reflector, $b$ :

With base reflector, 1: Benzoic acid and 2: Stearic acid.

Statistical analysis using t-test showed that there was a significant difference between the SHE when the base reflectors were in use and when it was not. This shows that regardless the presence or type of heat storage materials in a DEBSC, there was a significant difference in the SHE for water at 5\% level of significance.

Table 3. Paired samples t-test of the water SHE of the DEBSCs at $5 \%$ level of significance

\begin{tabular}{|c|c|c|c|c|c|c|}
\hline & & & $\begin{array}{l}\mathrm{NHS}_{\mathrm{b}}- \\
\mathrm{NHS}_{\mathrm{a}}\end{array}$ & $\begin{array}{l}{ }^{1} \mathrm{LHS}_{\mathrm{b}}- \\
{ }^{1} \mathrm{LHSa}\end{array}$ & $\begin{array}{l}{ }^{2} \mathrm{LHS}_{\mathrm{b}}- \\
{ }^{2} \mathrm{LHS}_{\mathrm{a}}\end{array}$ & $\begin{array}{l}\mathrm{SHS}_{\mathrm{b}}- \\
\mathrm{SHS}_{\mathrm{a}}\end{array}$ \\
\hline \multirow{5}{*}{$\begin{array}{c}\text { Paired } \\
\text { Differences }\end{array}$} & Mean & & 0.10 & 0.12 & 0.14 & 0.08 \\
\hline & Std. Devi & ation & 0.14 & 0.14 & 0.12 & 0.11 \\
\hline & Std. Error & Mean & 0.01 & 0.01 & 0.01 & 0.01 \\
\hline & $95 \%$ & Lower & 0.11 & 0.14 & 0.16 & 0.09 \\
\hline & $\begin{array}{l}\text { Confidence } \\
\text { Interval }\end{array}$ & Upper & 0.08 & 0.11 & 0.13 & 0.07 \\
\hline \multirow{2}{*}{\multicolumn{3}{|c|}{$\begin{array}{l}\mathrm{t} \\
\mathrm{df}\end{array}$}} & 11.5 & 14.5 & 19.5 & 11.8 \\
\hline & & & 270 & 270 & 270 & 270 \\
\hline \multicolumn{3}{|c|}{ Sig. (2-tailed) } & 0.00 & 0.00 & 0.00 & 0.00 \\
\hline
\end{tabular}

Where; NHS: No heat Storage, LHS: Latent heat storage, SHS: Sensible heat storage, a: Without a base reflector, b: With base reflector, 1: Benzoic acid and 2: Stearic acid.

\subsection{Temperature Change of Heat Storage Materials}

The use of the base reflectors was observed to influence the temperature rise of the heat storage materials. Figure 7 shows the temperature of heat storage materials in the DEBSCs with and without base reflectors. Using the base reflectors, the temperature of benzoic acid attained was over $11{ }^{\circ} \mathrm{C}$ higher than when the base reflectors were not used, while that of palm olein was over $20{ }^{\circ} \mathrm{C}$ higher. On the other hand, using the base reflectors initially made the temperature of stearic acid to be $13{ }^{\circ} \mathrm{C}$ higher than when the base reflector was not used, but it was later $10{ }^{\circ} \mathrm{C}$ lower.

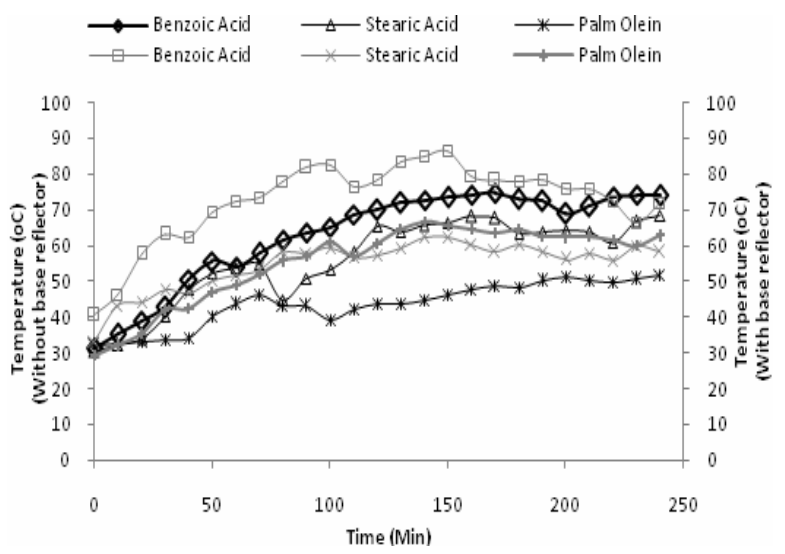

Figure 7.The temperature of heat storage materials in the DEBSCs with and without base reflectors

Table 4. Paired samples t-test of the temperature of the heat storage materials in the DEBSCs

\begin{tabular}{|c|c|c|c|c|c|}
\hline & & & $\begin{array}{c}\text { Benzoic Acid }{ }^{\mathrm{x}}- \\
\text { Benzoic Acid }\end{array}$ & $\begin{array}{l}\text { Stearic } \text { Acid }^{\mathrm{X}}- \\
\text { Stearic } \text { Acid }^{\mathrm{y}}\end{array}$ & $\begin{array}{c}\text { Palm Olein }^{\mathrm{x}}- \\
\text { Palm Olein }^{\mathrm{y}}\end{array}$ \\
\hline \multirow{5}{*}{$\begin{array}{c}\text { Paired } \\
\text { Differences }\end{array}$} & \multicolumn{2}{|l|}{ Mean } & 3.36 & 29.76 & 128.88 \\
\hline & \multicolumn{2}{|c|}{ Std. Deviation } & 38.71 & 48.22 & 58.98 \\
\hline & \multicolumn{2}{|c|}{ Std. Error Mean } & 7.74 & 9.64 & 11.80 \\
\hline & 95\% Confidence & Lower & 19.34 & 9.86 & 153.23 \\
\hline & Interval & Upper & 12.62 & 49.66 & 104.54 \\
\hline $\mathrm{t}$ & & & 0.43 & 3.09 & 10.93 \\
\hline df & & & 24 & 24 & 24 \\
\hline Sig. (2-tailed) & & & 0.67 & 0.01 & 0.00 \\
\hline
\end{tabular}

Where: $\mathrm{x}$ - in DEBSC with base reflector; $\mathrm{y}$ - in DEBSC without base reflector 

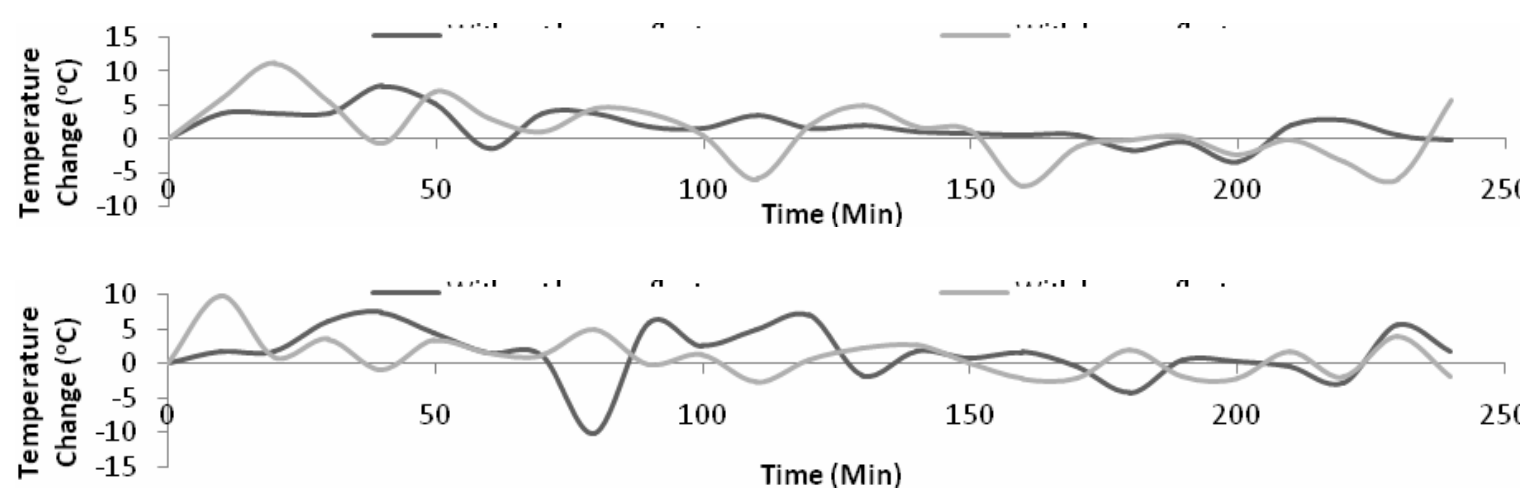

(a)

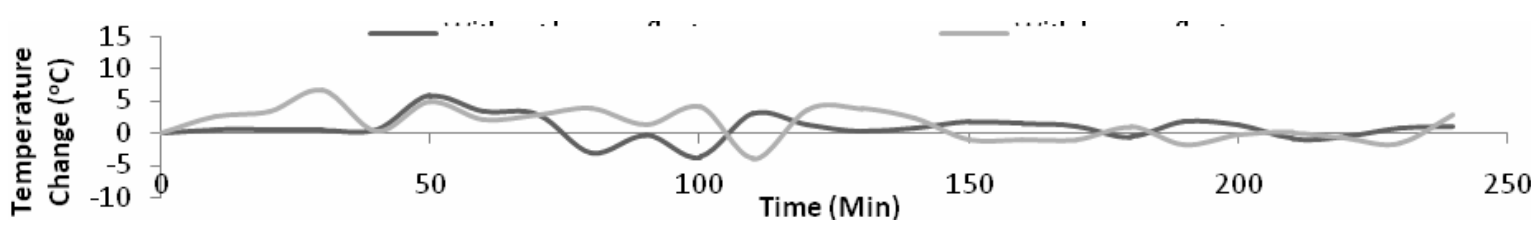

Figure 8. Change in temperature of the heat storage materials in the DEBSCs with and without base reflectors (a: benzoic acid; b: stearic acid; c: palm olein)

Figure 8a-c show the trend of the change in the temperature of the heat storage materials in the DEBSCs i.e. benzoic acid, stearic acid and palm olein respectively. From Figures $8 \mathrm{a}$ and $\mathrm{c}$, the temperature change of benzoic acid and palm olein in the DEBSCs without base reflectors was more stable compared to when the base reflectors were in use. This can be attributed to the heat loss from the bottom of the cavity containing the heat storage materials when it was exposed to the solar radiation from the base reflectors. On the other hand, Figure $8 \mathrm{~b}$ showed that a more stable temperature change was attained by stearic acid when the base reflector was in use. This was because when the base reflectors were used, stearic acid attained its melting point temperature faster and other heat input became latent.

The result of the t-test paired sample conducted on the temperature of the heat storage materials in the DEBSCs is shown in table 4. It was observed that the type of effect the base reflectors have on the temperature of the heat storage materials depended on the type of heat storage materials. The use of a base reflector affects the temperature of benzoic acid in the DEBSCs, while there was no significant difference between the temperature of some heat storage materials (stearic acid and palm olein) in the DEBSCs with and without base reflectors at $5 \%$ level of significance.

\subsection{Energy Stored in Heat Storage Materials}

As a result of the temperature rise of the heat storage materials, energy was stored. The average energy stored by benzoic acid, stearic acid and palm olein in the DEBSCs without base reflectors were; 178,461 and 110 $\mathrm{kJ}$ respectively, while with base reflectors, the energy stored were; 182, 503 and $245 \mathrm{~kJ}$ respectively. Figure 9 shows the variation in the amount of energy stored in the heat storage materials. The energy stored in benzoic acid varied from $21-236 \mathrm{~kJ}$ within $170 \mathrm{~min}$ for the DEBSC without base reflectors, while with base reflectors, within $150 \mathrm{~min}$, the energy stored rose from
$32-250 \mathrm{~kJ}$. For stearic acid, the energy stored when the base reflector was not in use increased from $13 \mathrm{~kJ}$ to 63 $\mathrm{kJ}$ within $100 \mathrm{~min}$; after which the stearic acid melted and the energy stored increased to $634 \mathrm{~kJ}$. When the base reflectors were used, the energy stored in the DEBSC with stearic acid rose from $70-140 \mathrm{~kJ}$ within $70 \mathrm{~min}$; after which the stearic acid melted and the energy stored increased to $662 \mathrm{~kJ}$. Within $240 \mathrm{~min}$, the energy stored in palm olein rose from around $6-180 \mathrm{~kJ}$ without the use of base reflectors, while with the use of base reflectors, the energy stored rose from $24-340 \mathrm{~kJ}$ within $140 \mathrm{~min}$. This shows that the base reflectors of a DEBSC can boost the amount of energy stored in some heat storage materials.

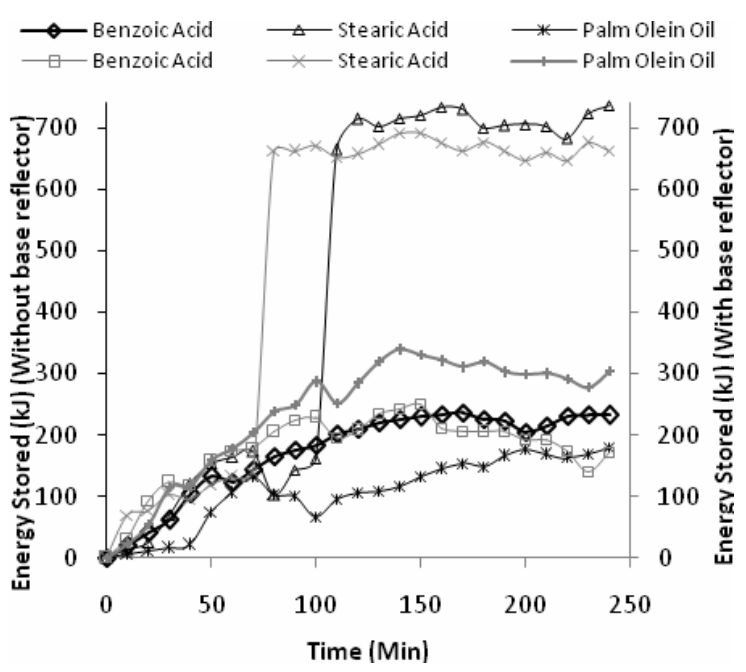

Figure 9. Energy stored by heat storage materials in the DEBSCs with and without base reflectors

\section{CONCLUSION}

The results in this paper show the varying effect of the presence and absence of a base reflector on the performance of a DEBSC with and without heat storage materials. It was discovered that using a base reflector in a DEBSC, 
1. Water temperature was boosted by up to $5-14$ ${ }^{\circ} \mathrm{C}$ depending on the type of heat storage materials used.

2. There was a boost in the temperature of heat storage materials.

3. A less steady change in the temperature of water.

4. A higher heating power (a DEBSC with stearic acid can attain $190 \mathrm{~W}$ ) can be attained

5. There was higher sensible heating efficiency due to more exposure points; $8,10.5,12.5$ and $6.6 \%$ boost was attained in the DEBSC with no heat storage, with benzoic acid, with stearic acid and with palm olein respectively.

6. Higher energy storage in benzoic acid and palm olein was possible

This study, therefore, justifies the need to increase the number of exposures to solar radiation in solar cookers, which can be extended to other solar thermal systems.

\section{REFERENCES}

[1] World Intellectual Property Organization.:Solar Cooking. Patent Landscape Report. Anna Salai, Nandanam: WIPO SCOPE e-KNOWLEDGE, 2011.

[2] Schwarzer, K. and Vieira da Silva, M.E.: Characterisation and design methods of solar cookers,Solar Energy, Vol. 82, pp.157-163, 2008

[3] Negi, B.S. and Purohit, I.: Experimental investigation of a box type solar cookeremploying a non-tracking concentrator,Energy Conversion and Management, Vol. 46, pp.577-604, 2005.

[4] Xiaofu, C.: Development and Application of Solar Cooker in China,SCI - Solar Cooker Review, Vol. 9, No. 2, pp.1-4. 2003.

[5] Kimambo, C.Z.M.: Development and performance testing of solar cookers,Journal of Energy in Southern Africa, Vol. 18 No. 3, pp.41-51, 2007.

[6] Mohurle, N.:Problem Statement. Climate Healers Available at: https://www.engineeringforchange .org/uploads/activity/22/22/446/1325006933380/Ni tinMohurle.pdf [Accessed 23 June 2014], 2011.

[7] McCluney, R.: Solar Cooker Reflector Optical Evaluation and Design Evolution. In FSEC Solar Cooker Report, Florida Solar Energy Center/ University of Central Florida, pp.1-13, 2001.

[8] Arabacigil, B., Yuksel, N. and Avci, A.: The Use of Paraffin Wax in a new Solar Cooker with Inner and Outer Reflectors, Thermal Science, DOI: 10.2298/TSCI121022031A, 2014.

[9] Ekechukwu, O.V., Ugwuoke, N.T.: Design and Measured Performance of a Plane Reflector Augmented Box-Type Solar Energy Cooker, Renewable Energy, Vol. 28, pp.1935- 1952, 2003.

[10] Mohammed, I.L., Aliyu, M.M. and Garba, I.: The Effect of Booster-Mirror Reflector on the Thermal Performance of a Truncated Pyramid Solar Thermal Cooker,Int. Journal of Engineering Research and Applications, Vol. 4, No. 5, pp.126-135, 2014.

[11] Nahar, N.M.: Design and Development of a Large Size Non-Tracking Solar Cooker. Journal of
Engineering Science and Technology, 4(3), pp. 264-271, 2009

[12] Adedipe, O., Abolarin, M.S.: Design and Implementation of a Novel Solar Cooker, Innovations in Science and Engineering, Vol. 1, pp. 97-103, 2011.

[13] Martin, R., Bond, T., Erickson, J., Rog, M., Crowley, C. et al.: Design of Solar Ovens for Use in the Developing World,International Journal for Service Learning in Engineering, Vol. 2, No. 1, pp. 78-91, 2006.

[14] Amer, E.M.: Theoretical and experimental assessment of a double exposure solar cooker, Energy Conversion and Management, 44, pp.2651-2663, 2003.

[15] Saravanan, K. and Janarathanan, B.: Comparative study of single and double exposure Box-type solar cooker,International Journal of Scientific \& Engineering Research, Vol. 5, No. 5, pp.620-624, 2014.

[16] Saravanan, K. and Janarthanan, B.: Energy and Exergy Analysis of Double Exposure Box-Type Solar Cooker,IJIRSET, Vol. 3, No. 6, pp.1310413113, 2014.

[17] Madhu, B., Bala, S.E., Nagarajen, P.K., Ravishankar, S. and Mageshbabu, D.: Improving the Yield of Freshwater and Exergy Analysis of Conventional Solar Still with Different Nanofluids, FME Transactions, Vol. 45, pp. 524-530, 2017.

[18] Ogueke, N.V., Anyanwu, E.E. and Ekechuuwu O.V.: A Review of Solar Water Heating Systems, Journal of Renewable and Sustainable Energy, Vol. 1, No. 4, DOI:10.1063/1.3167285, 2009.

[19] Tiwari, A.: A Review on Solar Drying on Agricultural Produce, Journal of Food Processing and Technology, Vol. 7, No. 9, DOI:10.4172/21577110.1000623, 2016.

[20] Jebaraj, S. and Srinivasa, R.P.: High-Efficiency Solar Oven for Tropical Countries, ARPN Journal of Engineering and Applied Sciences, Vol. 10, No. 21, pp. 10213-10217, 2015.

\section{NOMENCLATURE}

$\begin{array}{ll}\text { NHS } & \text { No heat storage } \\ \text { LHS } & \text { Latent heat storage } \\ \text { SHS } & \text { Sensible heat storage } \\ \text { SHE } & \text { Sensible heat efficiency } \\ \text { L }_{\mathrm{f}} & \text { Latent heat of fusion } \\ \mathrm{M}_{\cdot \mathrm{pt}} & \text { Melting point } \\ \mathrm{C} & \text { Specific heat } \\ \mathrm{M} & \text { Mass } \\ \mathrm{T} & \text { Temperature } \\ \text { Q } & \text { Heating power } \\ \mathrm{A}_{\mathrm{s}} & \text { Surface Area } \\ \mathrm{I}_{\mathrm{o}} & \text { Solar radiation intensity }\end{array}$

\section{Greek symbols}

$\begin{array}{cl}\rho & \text { Density } \\ \Delta \mathrm{T} & \text { Temperature difference } \\ \Delta \mathrm{t} & \text { Time difference }\end{array}$




\section{Superscripts}

$1 \quad$ Benzoic acid

2 Stearic acid

\section{Subscripts}

hs Heat storage material

w Water

a Without base reflector

b With base reflector

\section{УТИЦАЈ БАЗНОГ РЕФЛЕКТОРА НА ПЕРФОРМАНСЕ СОЛАРНОГ ШТЕДЫАКА ТИПА КУТИЈЕ СА ДВОСТРУКОМ ЕКСПОЗИЦИЈОМ СА И БЕЗ МАТЕРИЈАЛА ЗА СКЛАДИШТЕЫЕ ТОПЛОТЕ}

\section{Б.О. Адетифа, А.К. Арему}

Експерименти са загревањем воде су изведени на четири штедњака типа кутије са двоструком експозицијом који имају различите материјале за складиштење топлоте (бензоеву киселину, стеаринску киселину, палмино уље и немају материјала за складиштење топлоте), при чему су базни рефлектори били отворени и затворени за сунчево зрачење. Извршена су прорачунавања промене температуре воде и материјала за складиштење топлоте, снаге за загревање воде, рационалне ефикасности загревања и количине енергије коју ускладиште материјали. Коришћењем базних рефлектора постигнуто је побољшање температуре воде од $20^{\circ} \mathrm{C}$ без материјала за складиштење топлоте, док је са материјалом побољшање било $6-15^{0} \mathrm{C}$. Утврђено је да се снага загревања повећава када се користе базни рефлектори; постигнута је разлика од 112, 60, 172 и $35 \mathrm{~W}$ у штедњацима без материјала, бензоеве киселине, олеинске киселине и палминог уља. Коришћењем базних рефлектора код штедњака повећава се рационална ефикасност загревања. Просечна енергија ускладиштена у бензоевој киселини, олеинској киселини, палмином уљу у штедњацима без базног рефлектора износила је: 178 , 461 и $110 \mathrm{~kJ}$, док је са базним рефлекторима ускладиштена енергија била: 182, 503 и 245 кJ. Присуство и одсуство базних рефлектора имало је утицаја на перформансе соларних штедњака типа кутије са двоструком експозицијом. 